\title{
DNA damage to human genetic disorders with neurodevelopmental defects
}

Youngsoo Lee*, Inseo Choi, Jusik Kim, and Keeeun Kim

Genomic Instability Research Center and Department of Biomedical Sciences, Ajou University School of Medicine, Suwon, Korea

\begin{abstract}
Although some mutations are beneficial and are the driving force behind evolution, it is important to maintain DNA integrity and stability because it contains genetic information. However, in the oxygen-rich environment we live in, the DNA molecule is under constant threat from endogenous or exogenous insults. DNA damage could trigger the DNA damage response (DDR), which involves DNA repair, the regulation of cell cycle checkpoints, and the induction of programmed cell death or senescence. Dysregulation of these physiological responses to DNA damage causes developmental defects, neurological defects, premature aging, infertility, immune system defects, and tumors in humans. Some human syndromes are characterized by unique neurological phenotypes including microcephaly, mental retardation, ataxia, neurodegeneration, and neuropathy, suggesting a direct link between genomic instability resulting from defective DDR and neuropathology. In this review, rare human genetic disorders related to abnormal DDR and damage repair with neural defects will be discussed.
\end{abstract}

Key words: DNA damage, DNA repair, Single-stranded DNA breaks, Double-stranded DNA breaks, Central nervous system diseases.

\section{Introduction}

Since Kelner [1,2] reported in late 1940s that damaged DNA could be corrected, our knowledge about DNA damage and repair has increased exponentially [3]. DNA damage can be divided into 2 broad categories: base damage and strand breaks. When bases are chemically modified or damaged, they can be removed and corrected by the base excision repair (BER) pathway. If there are bulky helix-distortion lesions, most likely due to ultraviolet (UV) exposure, nucleotide excision repair (NER) mechanisms are activated. The DNA mismatch repair (MMR) pathway recognizes and repairs erroneous insertion, deletion and mis-incorporation of bases [3,4]. In 2015, the Nobel Prize in Chemistry was awarded to 3 DNA damage repair researchers: Tomas Lindahl (Emeritus group leader at Francis Crick Institute and Emeritus director of Cancer Research at Clare Hall Laboratory, UK., for BER), Aziz Sancar (Sarah Graham Kenan Professor of Biochemistry and Biophysics, University of North Carolina School of Medicine, USA., for NER) and Paul Modrich (James B. Duke Professor of Biochemistry at Duke University School of Medicine, USA., for MMR) for their research into mapping the mechanisms that underlie DNA damage repair at a detailed molecular level. On the other hand, DNA strand breaks could happen to one or both strands. Organisms have developed sophisticated mechanisms to deal with either DNA single strand breaks (SSBs) or DNA double strand breaks (DSBs) [3-6]. DNA DSB repair mechanisms are further divided into 2 major distinct pathways: homologous recombination repair (HRR) and non-

Received: 2 November 2015, Revised: 21 November 2015, Accepted: 23 November 2015, Published: 30 June 2016

${ }^{*}$ Corresponding author: Youngsoo Lee, Ph.D.

Genomic Instability Research Center, Ajou University School of Medicine, 164 Worldcup-ro, Yeongtong-gu, Suwon 16499, Korea.

Tel: +82-31-219-7805, Fax: +82-31-219-7802, E-mail: ysoolee@ajou.ac.kr

Conflict of interest: The authors declare that they do not have any conflicts of interest.

(ac) This is an open-access article distributed under the terms of the Creative Commons Attribution Non-Commercial License (http://creativecommons.org/licenses/by-nc/4.0/) which permits unrestricted non-commercial use, distribution, and reproduction in any medium, provided the original work is properly cited.

(c) Copyright 2016 by the Korean Society of Medical Genetics 
homologous end joining (NHEJ) $[3,4,6]$.

The ability to maintain genomic integrity by controlling the balance between DNA damage and repair is a fundamental feature of all living organisms. DNA damage triggers the DNA damage response (DDR) which activates not only DNA damage repair but also cell cycle checkpoints/arrest, programmed cell death and cellular senescence $[3,6,7]$. However, when defects in DDR happen in living multicellular organisms, particularly in human beings, they lead to rare genetic diseases with complex consequences such as developmental delay/defects, premature aging, infertility and immune system defects [3]. Additionally genomic instability resulting from DNA damage is one of the hallmarks of tumorigenesis [4]. A certain group of human syndromes are characterized by unique neurological manifestations including microcephaly, mental retardation, ataxia with cerebellar defects, neurodegeneration, and neuropathy $[5,6,8,9]$. These neurological phenotypes are more evident in genetic disorders with faulty DNA strand break detection or repair mechanisms. In this review, we discuss the current state of knowledge regarding human syndromes with neurological symptoms due to defects in the DNA strand break repair pathway.

\section{Pathways of DDR and DNA Strand Break Repair}

DNA strand breaks could happen to either one or both strands. Oxidative stress is the most common source for DNA SSB. SSBs can also be caused by the abortive activity of DNA topoisomerase I (TOP1) whereby TOP1 is covalently connected to the 3 ' - end of DNA strand breaks $[5,6,10]$. Several proteins are involved in the detection and end processing of SSB repair. Poly(ADP-ribose) polymerase 1 (PARP1) is one of the first proteins recruited to DNA break sites, then $X$-ray repair crosscomplementing protein 1 (XRCC1) is recruited and brings with it multiple proteins, including DNA polymerase $\beta(P O L \beta)$, polynucleotide kinase phosphatase (PNKP), aprataxin (APTX), DNA ligase III (LIG3), and tyrosyl-DNA phosphodiesterase 1 (TDP1). These proteins are essential for the processing of broken DNA ends and for the restoration of the 3 '-hydroxyl and $5^{\prime}$-phosphate moieties (Fig. 1) $[5,6,10]$.

There are two major pathways to repair DSBs: HRR, which is restricted to the late $S$ to $G 2$ phases of cell cycle as it requires sister chromatids as a template to accurately copy the intact DNA sequence and repair the damage; and NHEJ, which is active throughout the cell cycle and in fully differentiated cells such as endogenous reactive oxygen species (ROS) hydrogen peroxide $\left(\mathrm{H}_{2} \mathrm{O}_{2}\right)$

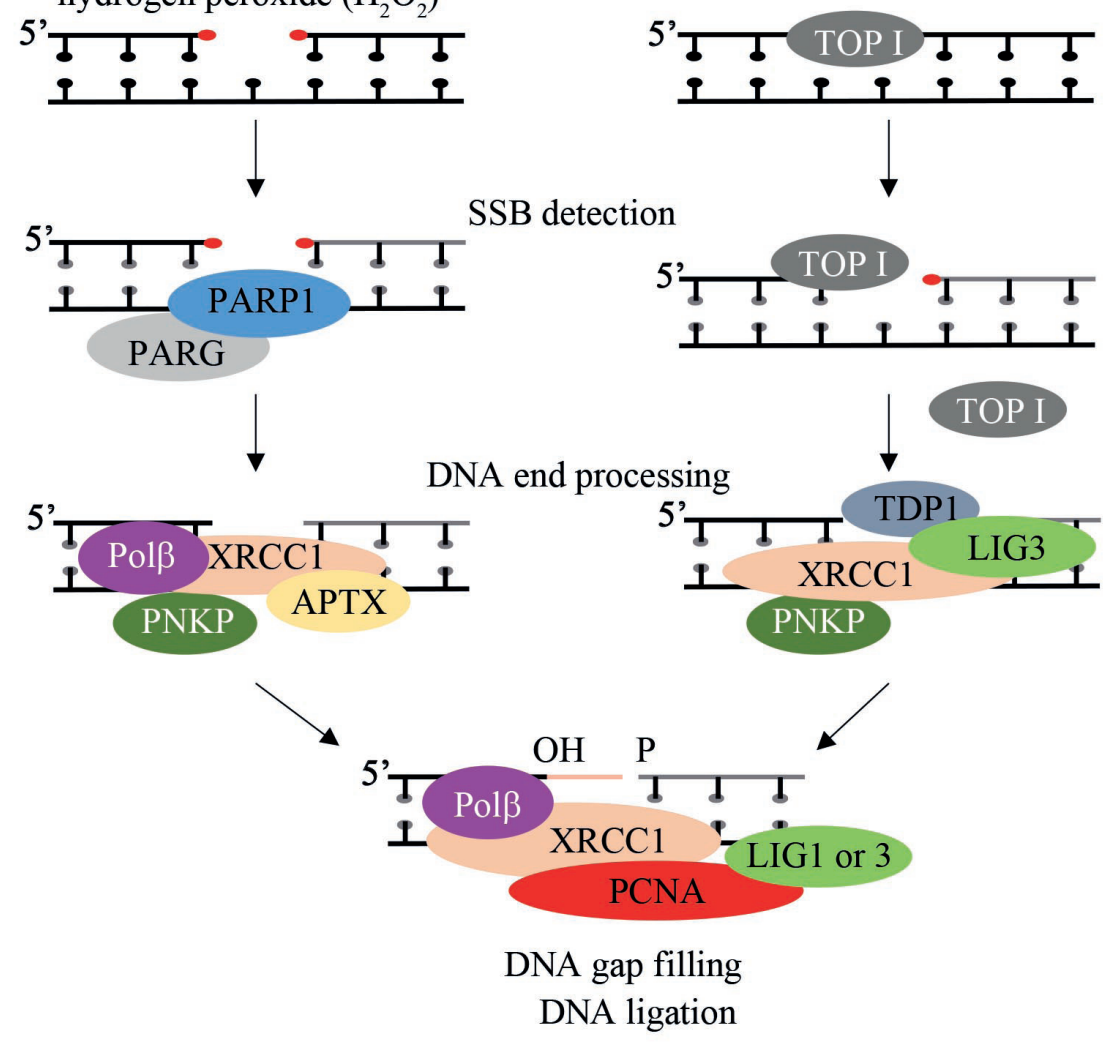

Topoisomerase I (TOP1)-DNA link

Fig. 1. DNA single strand break (SSB) repair. DNA SSBs could result from oxidative attacks by reactive oxygen species (ROS) or from abnormal topoisomerase I (TOP1) activity. Poly(ADP-ribose) polymerase I (PARP1) is one of first proteins recruited to sites of SSB. Poly(ADP-ribosyl)ation is also controlled by Poly(ADP-ribose) glycohydrolase (PARG). After the damage detection step, X-ray repair crosscomplementing protein 1 (XRCC1) recruits several key proteins needed for broken DNA end processing and for DNA ligation including DNA polymerase $\beta$ (POL $\beta$ ), polynucleotide kinase phosphatase (PNKP), aprataxin (APTX), tyrosyl-DNA phosphodiesterase 1 (TDP1), and DNA ligase III (LIG3) to the sites of damage. Depending on the size of gap, either DNA ligase I (LIG1) or LIG3 is required for gap filling. 
neurons. HRR and NHEJ require distinct groups of proteins for their pathways $[3,11]$. The HRR pathway starts with a resection of the broken DNA ends by the MRE11-RAD50-NBS1 (MRN) complex and CtBP-interacting protein (CtIP) to produce a single stranded DNA which the replication protein A (RPA) trimers bind to with high affinity. The breast cancer 2 (BRCA2) protein mediates displacement of RPA and binding of RAD51 to the single-stranded DNA. RAD51, together with other proteins, invades the homologous DNA strands to find and copy intact DNA sequences (Fig. 2) [12-14]. In contrast, the NHEJ process is initiated by the binding of the KU70/80 heterodimer to both broken ends of the DNA strands resulting in the recruitment of DNA dependent protein kinase catalytic subunit (DNA-PKcs) to the sites of DSBs. Additional factors including ARTEMIS and DNA polymerases process the broken DNA ends to create compatible DNA ends for ligation. Finally the protein complex composed of
DNA ligase IV (LIG4), XRCC4 and XRCC4 like factor (XLF) ligates the 2 processed DNA ends (Fig. 2) $[3,11,15,16]$.

Though our current understanding of DDR dynamics, particularly for the recognition of DNA DSB, is quite advanced, the entire picture of DDR is still not complete. Once DNA DSB takes place, the MRN complex immediately moves to the sites of DSB and recruits ataxia telangiectasia mutated (ATM) for its activation. Consequently ATM phosphorylates numerous downstream proteins including histone $\mathrm{H} 2 \mathrm{AX}$ that provides a binding platform for the mediator of DNA damage checkpoint protein 1 (MDC1), which is another ATM kinase substrate $[4,17-20]$. After the ubiquitination steps by ring finger protein (RNF) 8 and RNF168, the tumor protein p53 binding protein 1 (53BP1) protein recognizes several histone modifications including H2AK13ub (ubiquitination), H2AK15ub, H2K79me (methylation), H4K2Ome, and H4K2Ome2 to promote NHEJ. The recruitment of BRCA1 to

Non-Homologous End Joining (NHEJ) Homologous Recombination Repair (HRR)
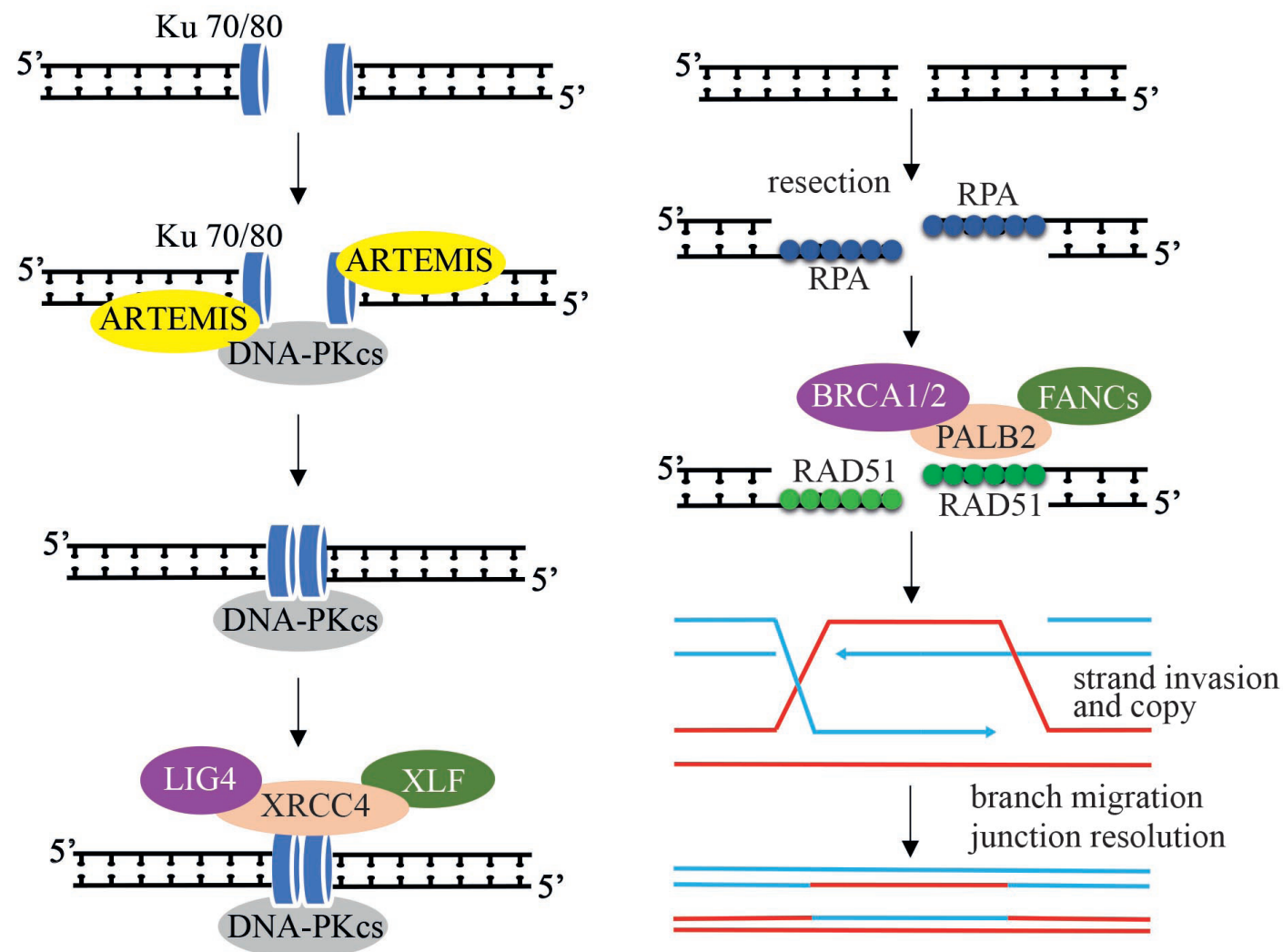

Fig. 2. DNA double strand break (DSB) repair. DNA DSBs can be repaired by either homologous recombination repair (HRR) or non-homologous end-joining (NHEJ) depending on the availability of a sister chromatid. Ku70/80 heterodimers bind to DSB, recruit DNA-PKcs and initiate NHEJ. After broken DNA end processing is done (e.g., help of ARTEMIS), the breaks are ligated by DNA ligase IV (LIG4), which interacts directly with X-ray repair cross-complementing protein 4 (XRCC4) and indirectly with XRCC4-like factor (XLF). During HRR, the resection results in a singlestranded DNA that is stabilized by replication protein A (RPA) and, later replaced by RAD51 with help from BRCA1, BRCA2, partner and localizer of BRCA2 (PALB2), and Fanconi anemia (FANC) proteins. After strand invasion and copy, the Holiday junction can be resolved by either the noncrossover or crossover mechanisms. 
A.
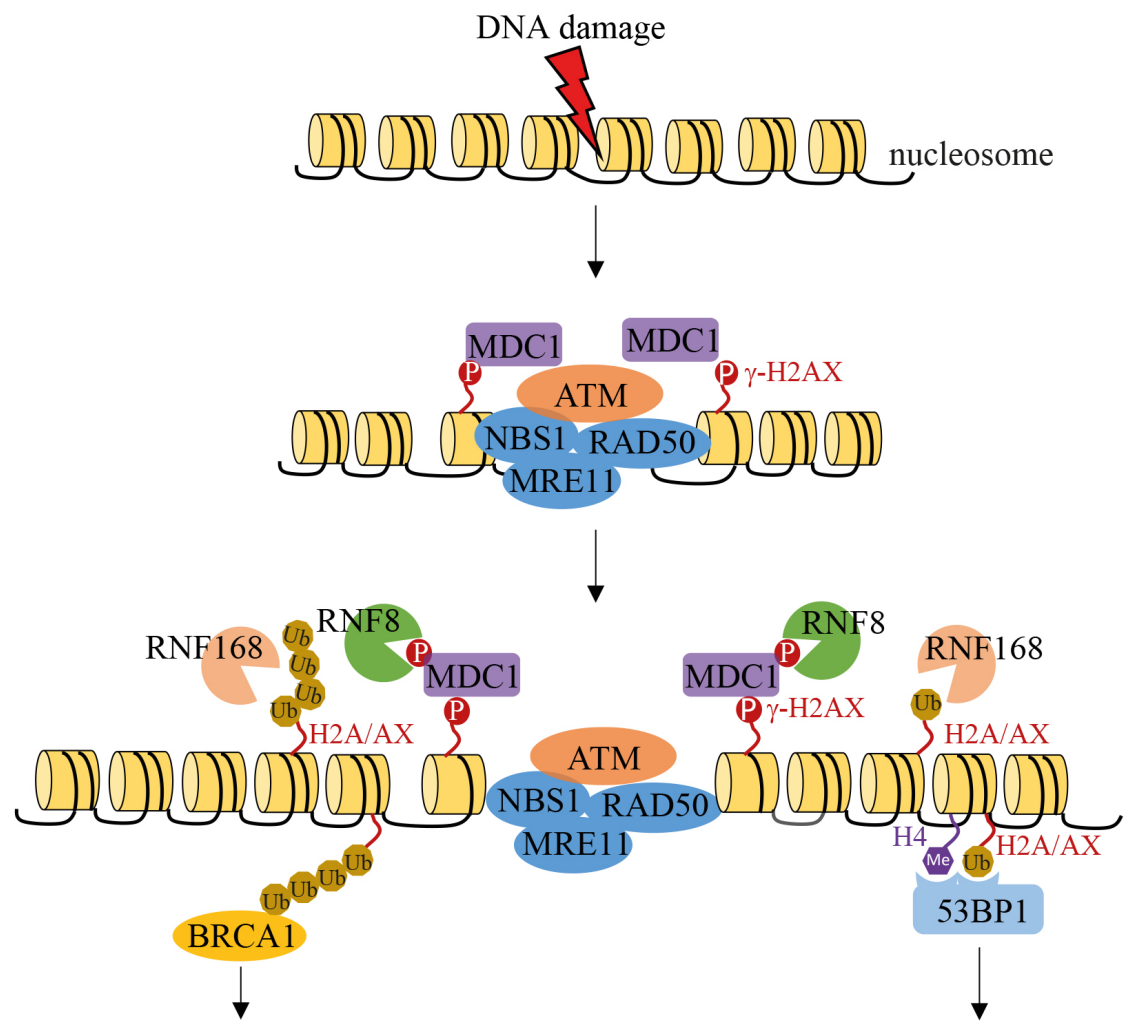

Homologous Recombination Repair (HRR)

Non-Homologous End Joining (NHEJ)

B.

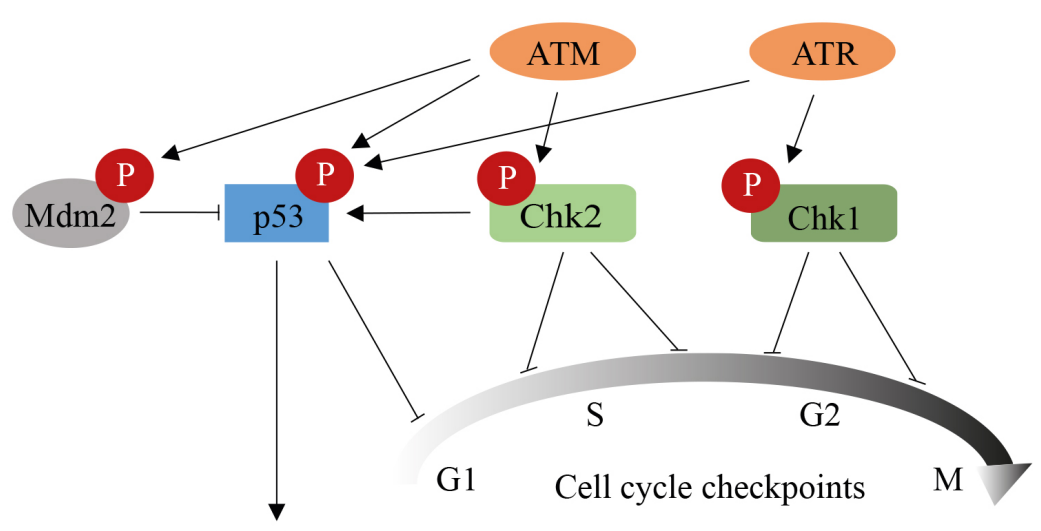

Apoptosis

Fig. 3. Detection of DNA double strand breaks (DSBs). (A) The immediate response to DNA DSBs. Upon DNA DSBs, the MRN (MRE11-RAD50-NBS1) complex recognizes and binds to the break sites to trigger DNA damage response (DDR). NBS1 recruits ataxia telangiectasia mutated (ATM) to the break site. Once ATM is activated by auto-phosphorylation, ATM phosphorylates many proteins including H2AX ( $\gamma$-H2AX-phosphorylated H2AX), and the mediator of DNA damage checkpoint protein 1 (MDC1). Phosphorylation (P) of MDC1 induces sequential ubiquitination (Ub) of several target proteins such as histone $\mathrm{H} 2 \mathrm{~A} / \mathrm{H} 2 \mathrm{AX}$ by RNF8 and RNF168. It seems that the recognition of poly-ubiquitinated histones by BRCA1 and its associated proteins promotes homologous recombination repair (HRR), while mono-ubiquitination and methylation of histones are recognized by 53BP1 for the promotion of non-homologous end joining (NHEJ) (H, histone; Me, methylation). (B) Similar to ATM, ataxia telangiectasia and Rad3 related (ATR) is also activated by DNA damage such as replication stress, and then phosphorylates numerous proteins some of which are also ATM phosphorylation targets. However, CHK2 and CHK1 are phosphorylated by ATM and ATR respectively upon DNA damage to regulate cell cycle checkpoints. 
sites of DSB boosted by CtIP phosphorylation, and displacement of 53BP1 by BRCA1 initiate the resection process for HRR during the Sand G2 phase (Fig. 3) [21-24].

Another protein kinase, ataxia telangiectasia and Rad3 related (ATR), responds to single-stranded DNA that occurs at stalled replication forks [25]. Similar to ATM, ATR has a protein kinase function, and shares common substrates (such as p53) with ATM. However, some proteins are unique to either kinase, e.g., ATM phosphorylates $\mathrm{CHK} 2$, whereas $\mathrm{CHK} 1$ is phosphorylated by ATR to regulate cell cycle checkpoints upon DNA damage (Fig. 3) [26].

\section{Faulty DDR in Neurodevelopmental Defects}

\section{Ataxia-telangiectasia mutated (ATM)}

As one of the early responders to DNA strand breaks, ATM (a member of the phosphatidylinositol 3-kinase family) phosphorylates a plethora of proteins immediately upon DNA damage including H2AX, NBS1, CHEK2, p53, MDM2, BRCA1, CTIP, and RAD9, which regulate programmed cell death and cell cycle checkpoints $[7,27,28]$. It is well known that mutations in the ATM gene cause the human genetic disease, ataxiatelangiectasia (A-T, also known as Louis-Bar syndrome) $[29,30]$. Clinical manifestations of A-T include telangiectasia, immune system defects, chronic infections, infertility and an increased risk of leukemia and lymphoma. The prominent clinical phenotypes of A-T are related to the nervous system such as progressive ataxia due to neurodegeneration in the cerebellum, chorea, neuropathy, and leukodystrophy [27-30]. A-T patients in Korea were rarely reported. The Korean patients recently reported showed limb and truncal ataxia with cerebellar atrophy, oculomotor apraxia with gaze-evoked nystagmus and choreoathetosis of the bilateral extremities [31]. These Korean A-T patients carry a known missense mutation (c.G8546C, p.Arg2849Pro substitution) and a novel intronic variant of intron 17 causing exon 18 skipping.

\section{Nibrin (NBN, NBS1)}

The MRN complex is critical for initiating DDR as well as DNA recombination. In the MRN complex; MRE11 has an endo/exonuclease activity, RAD50 is required for binding to DNA broken ends, and NBN modulates DDR by interacting with ATM, ATR, and possibly DNA-PK $[12,20]$. NBN is also a major player for the intra-S phase checkpoint in an ATM dependent manner [32,33]. Several mutations in the NBN gene were reported to cause Nijmegen breakage syndrome (NBS), including the five nucleotide deletion in exon 6 (657del5), the
p.lle171Val mutation, and the p.Arg215Trp substitution [19,34]. NBS patients have a characteristic facial appearance with a combination of a receding forehead, a receding mandible and a prominent midface, often referred to as a 'bird-like face.' They also show growth retardation, short stature, immunodeficiency, microcephaly, and mental retardation $[19,34]$. Interestingly Japanese patients with the lle171Val substation in the NBN gene did not show any signs of NBS, but developed aplastic anemia [35].

\section{Meiotic recombination 11 homolog A (S. Cerevisiae) (MRE11A)}

The endo- and exonuclease functions of MRE11 act on asymmetric openings of DNA hairpin loops and processes broken DNA ends to facilitate DNA strand break repair $[12,19]$. MRE11 is also involved in HRR and telomere length maintenance [12]. There are more than 10 different known homozygous or compound heterozygous mutations, which result in ataxiatelangiectasia-like disorder 1 (ATLD1), including the p.Arg633Ter premature truncation mutation, the p.Asp113Gly missense mutation, and the compound heterozygous mutation of a p.Asn 117Ser missense and a pArg572Ter premature termination [36]. Only very detailed linkage analyses are able to distinguish these two syndromes as the ATM gene is located at chromosome 11q22-23 and the MRE11A gene is located at chromosome 11q21. The clinical features of ATLD1 include progressive cerebellar ataxia resulting from neurodegeneration, oculomotor apraxia, and increased susceptibility to radiation, but ATLD1 has a milder clinical course than A-T $[12,19,36]$. Unlike in A-T, ATLD1 patients do not generally show signs of telangiectasia and immune deficiency.

\section{Proliferating cell nuclear antigen (PCNA)}

Baple et al. [37] reported that a homozygous missense (c.G683T, p.Ser228lle) mutation in the PCNA gene is compatible with viability in humans, however it results in a rare syndrome characterized by neurological abnormalities called, ataxiatelangiectasia like disorder 2 (ATLD2). PCNA is an essential DNA replication protein and plays a key role in several DNA damage repair mechanisms that occur during the final stages of the repair process [38,39]. Interestingly, the p.Ser228lle mutation did not influence the protein level of PCNA during DNA replication, yet mutant cells derived from patients were sensitive to UV irradiation and had defective NER mechanisms. The authors [37] found four patients from one family that displayed developmental retardation, learning difficulties, hearing loss, 
progressive ataxia, progressive muscle weakness, dysphagia, dysarthria, telangiectasia and photosensitivity. All patients also showed dwarfism.

\section{Ataxia-telangiectasia and Rad3-related (ATR)}

As a member of the phosphatidylinositol 3-kinase family, ATR is an early and essential regulator of DNA damage repair, cell cycle checkpoints, and DNA replication/stability [25]. Similar to ATM, ATR is a protein kinase that is activated by a singlestranded DNA, and, once activated, phosphorylates numerous proteins including BRCA1, CHEK1, MCM2, RAD17, RPA2, SMC1 and p53 [7,25]. Mutations in the ATR gene cause 1 of 2 distinct syndromes: Seckel syndrome (SCKL) 1 or cutaneous telangiectasia and cancer syndrome, familial (FCTCS). SCKL1 is characterized by intrauterine growth retardation, dwarfism, microcephaly, mental retardation and a 'bird-headed' facial appearance (a beak-like protrusion of the nose, narrow face and receding lower jaw) which is also common in NBS and LIG4 syndromes [34,40-42]. SCKL1 is caused by ATR mutations such as compound heterozygous mutations of a p.Met1159lle substitution and a c.C6897+464G, Val2300GlyfsTer75 premature termination, or the p.Asp 1897Tyr substitution and one 540-kilobase deletion [43,44].

However, the missense mutation of c.A6431G, p.GIn2144Arg substitution leads to a new syndrome called FCTCS with telangiectasia that appears during infancy in both sun-exposed and sun-protected sites. Thinning eyebrows, patchy alopecia, thin dental enamel and dental caries, developmental anomalies of hair, nails, and a predisposition to cancer, predominantly oropharyngeal cancer are all characteristics of FCTCS [45].

\section{Retinoblastoma-binding protein 8 (RBBP8), also known as CtBP-interacting protein (CtIP)}

Clinically similar to SCKL1, SCKL2 (also known as microcephalic primordial dwarfism 2) occurs due to mutations in the RBBP8 gene, such as the c.T2347+53G resulting in an alternatively spliced transcript and a truncated protein or the c.C298T, p.Arg 100Trp substitution [46,47]. SCKL2 patients displayed growth retardation, microcephaly, mental retardation, a characteristic 'bird-headed' facial appearance, and sensitivity to DNA damaging reagents [46-48]. The RBBB8 protein binds directly to retinoblastoma protein $(\mathrm{Rb})$ and $\mathrm{BRCA} 1$ to regulate cell proliferation and transcription and to control cell cycle checkpoints. It has an endonuclease function for DNA damage repair, particularly microhomology-mediated alternative end joining and DNA end processing $[13,49]$.
A homozygous 2-base pair deletion in exon 11 which causes a frameshift mutation and a premature termination were found in seven members of a consanguineous Pakistani family who showed microcephaly, sharply sloping foreheads, mental retardation, anonychia congenita, digital malformation (polydactyly and synpolydactyly), and white spots on the skin of the hands and feet $[48,50]$. This syndrome is called Jawad syndrome (JWDS; also known as Kelly syndrome, or microcephaly with mental retardation and digital anomalies).

Five more genetically distinct SCKLs, numbered from 4 to 8 , are currently found. All SCKL syndromes share similar clinical features such as pre- and postnatal growth retardation, microcephaly with mental retardation, and specific dysmorphic features (receding chin, high forehead; a 'bird headed' facial appearance). All responsible genes for SCKL4 to SCKL7 are involved in the maintenance and function of the centrosome: SCKL4-CENPJ (centromeric protein J, also known as centrosomal p4.1-associated protein [CPAP]), SCKL5-CEP152 (centrosomal protein, 152-KD), SCKL6-CEP63 (centrosomal protein, 63-KD), and SCKL7-NIN (Ninein, also known as GSK3 $\beta$-interacting protein) [51-54]. Interestingly, it has been found that two members from consanguineous marriages carry a homozygous mutation for a 1-base pair deletion (c.3372+6delC) in intron 20 of the DNA2 gene resulting in a truncation of one transcript and abnormal slicing of another 2-transcripts. This mutation in the DNA2 gene (responsible for SCKL8) causes short stature, 'bird headed' facial features, microcephaly and mental retardation $[47,55]$. However, patients with mutations in the DNA2 gene (p.Arg284His, p.Lys313Glu, or Val723lle substitution) generally display muscle weakness, mainly affecting the lower limbs, abnormal gait with hyperlordosis, external ophthalmoplegia, exercise intolerance, and mitochondrial DNA deletion [56]. This symptom is called progressive external ophthalmoplegia with mitochondrial DNA deletions, autosomal dominant 6 (PEOA6).

\section{Ring finger protein 168 (RNF168)}

As one of the E3 ubiquitin ligases involved in DDR, RNF168 acts with $\mathrm{E} 2$ ubiquitin-conjugating enzyme (UBC13) to amplify the RNF8-dependent ubiquitination of histones upon DNA damage, particularly in DNA DSBs. This catalyzes the formation of Lys63 linked ubiquitin conjugate and promotes the ubiquitination of $\mathrm{H} 2 \mathrm{~A}$ and $\mathrm{H} 2 \mathrm{AX}$ [18]. When the RNF168 gene is mutated, e.g., by the compound heterozygous mutation of 1-base pair duplication (397dupG) and a 4-base pair deletion (1323delACAA) which results in a frameshift mutation and a premature protein truncation, or a p.Arg131Ter substitution resulting 
in the complete loss of the protein, RIDDLE syndrome occurs $[57,58]$. RIDDLE stands for radiosensitivity, immunodeficiency, dysmorphic features, and learning difficulties. Some patients also showed microcephaly, impaired motor control, ataxia and ocular telangiectasia [57,58].

\section{Defective DNA SSB Repair in Abnormal Neurodevelopment}

\section{Tyrosyl-DNA phosphodiesterase 1 (TDP1)}

During replication, topoisomerases relieve the topological tension on the DNA double-helical structure. These enzymes also create a covalent protein-DNA intermediate, which is hydrolyzed by tyrosyl-DNA phosphodiesterases (TDPs) [59]. TDP1 is particularly involved in the catalysis of stalled TOPI and DNA complexes. Several members of a Saudi Arabian family were affected with peripheral axonal motor and sensory neuropathy, muscular atrophy, cerebellar ataxia, and seizure due to a homozygous mutation in the TDP1 gene (c.A1478G, p.His493Arg) [60]. The patients of Spinocerebellar ataxia, autosomal recessive, with axonal neuropathy (SCAN1) did not show a predisposition to neoplasia or dysfunctional proliferation of tissues, rather they had defective DNA SSB repair in terminally differentiated, non-dividing neuronal cells [61].

\section{TRAF- and TNF receptor-associated protein (TTRAP),} also known as tyrosyl-DNA phosphodiesterase 2 (TDP2)

TDP2 was originally identified as a protein that interacted with CD40 and TRAFs in order to regulate nuclear factor kappa $\mathrm{B}(\mathrm{NF}-\kappa \mathrm{B})$ signaling pathways [62]. Cortes Ledesma et al. [63] then discovered that the protein also cleaved $5^{\prime}$-phosphotyrosyl bonds between topoisomerase II and DNA, thus restoring the $5^{\prime}$-phosphate terminus for proper DNA ligation. Recently it has been reported that 3 brothers in a consanguineous Irish family and one additional unrelated patient developed progressive ataxia, intellectual disability (I0 30-40), and symptomatic generalized epilepsy $[64,65]$. Exome and Sanger sequencing analysis revealed 2 mutations in the TDP2 gene; one was a missense variant (c.T919C, p.lle307Val) which is most likely benign, and the other was the putative splice-donor mutation (c.G425+1A) which results in the insertion of a premature stop codon within the N-terminal half of the encoded protein [64]. This syndrome is currently unnamed.

\section{Aprataxin (APTX)}

APTX, a member of the histidine triad (HIT) superfamily, interacts with DNA damage repair proteins including XRCC1, PARP1 and XRCC $4[5,66,67]$. The main function of APTX is to resolve aberrant DNA ligation intermediates such as adenylate groups linked to the $5^{\prime}$-phosphate ends of broken DNA, $5^{\prime}$-monophosphoramidate, and diadenosine tetraphosphate [68]. Mutations in the APTX gene cause a genetic disease called ataxia, early-onset, with oculomotor apraxia and hypoalbuminemia $(E A O H$, also known as ataxia-oculomotor apraxia 1 [AOA1]) $[5,69,70]$. Clinical manifestations include oculomotor apraxia, progressive ataxia, peripheral neuropathy and choreoathetosis $[5,8,71]$. Even though the neurological symptoms are quite similar to those of $A-T$, the onset of symptoms tends to be later and lacking in extra-neurologic features [71]. Several mutations in the APTX gene are reported to cause this syndrome. The most common mutation is the insertion of a T after nucleotide 167 and the p.Pro206Leu mutation [69]. AOA1 patients with complete deletion of the APTX gene were also found [72,73].

\section{Senataxin (SETX)}

Similar to AOA1, Spinocerebellar ataxia, autosomal recessive 1 (SCAR1, also known as ataxia-oculomotor apraxia 2 [AOA2]) is a hereditary disorder with neurodegenerative features, including progressive cerebellar ataxia, cerebellar atrophy, axonal sensorimotor peripheral neuropathy, tremor, and oculomotor apraxia $[8,74]$. The gene responsible for this syndrome is SETX which has a DNA/RNA helicase domain suggesting that it might be involved in DNA and RNA processing [74]. AOA2 cells were very sensitive to oxidative DNA stress but not to ionizing radiation (IR) indicating that SETX could contribute to a certain type of DDR [75]. Several mutations of the SETX gene have been found including the $p$.Arg1363Ter premature termination mutation and the $\mathrm{pGIn868Ter}$ protein truncation mutation [74]. Four individuals from one family displayed AOA2 characteristics with the p.Pro629Ser substitution in the PIK3R5 (phosphatidylinositol 3-kinase, regulatory subunit 5; called ataxia-oculomotor apraxia 3 [AOA3]) gene and no mutations in the SETX gene [76]. PIK3R5 does not have an exclusive role in DNA damage repair.

\section{Polynucleotide kinase 3-prime phosphatase (PNKP)}

For DNA strand break repair, the ends of broken strands must have a 5 '-phosphate and a 3 '-hydroxyl group for proper ligation. PNKP has a dual function (5'-kinase and $3{ }^{\prime}$-phosphatase) as it can process both damaged DNA ends [77]. Certain mutations in the PNKP gene, such as the p.Glu326Lys substitution, a 
homozygous 17-base pair duplication resulting in a frameshift and premature termination, or a compound heterozygous 17base pair deletion and duplication, cause microcephaly, seizures, and developmental delay (MCSZ; also known as epileptic encephalopathy, early infantile, 10 [EIEE10]) $[5,8,78]$.

Other complex mutations in the PNKP gene include the p.Gly375Trp substitution, a 5-base pair insertion (c.1322 1323insAGCCG), a 3-base pair deletion (c.1221_1223del), or an 8-base pair insertion (c.1549_1550ins). These mutations lead to Ataxia-oculomotor apraxia 4 (AOA4) which is characterized by ataxia, cerebellar atrophy, oculomotor apraxia, peripheral neuropathy and a prominent dystonia that attenuates with age [79].

\section{Defective DNA DSB Repair in Abnormal Neurodevelopment}

\section{Protein kinase, DNA-activated, catalytic subunit (PRKDC), also known as DNA protein kinase (DNA-PK)}

DNA-PKcs, encoded by the PRKDC gene, is a serine/threonineprotein kinase required for NHEJ and for V(D)J recombination during the immune response. The holoenzyme is composed of DNA-PKcs and the KU70/80 heterodimer [80]. The research group led by Penny Jeggo found a patient with the compound heterozygous mutation of a p.Ala3574Val substitution and a missing exon 16 [81]. This patient displayed typical signs of severe combined immunodeficiency (SCID) such as an absence of circulating B and T cells and normal NK cells. However, the patient also had growth retardation, persistent oral and perineal candidiasis, and dysmorphic features including a prominent forehead, a wide nasal bridge, a long philtrum and a small chin. The neurological features observed in this patient were microcephaly, simplified gyral pattern, pachygyria, thin corpus callosum, small hippocampus, hypomyelination, and seizures.

\section{Non-homologous end-joining factor 1 (NHEJ1), also known as XRCC4-like factor (XLF) or Cernunnos}

NHEJ1 interacts with the LIG4-XRCC4 complex to stimulate it, yet accumulation of NHEJ 1 at the damaged site is KU dependent and XRCC4 independent [16]. This protein is expressed in human embryonic brain including the telencephalic ventricular and subventricular zones and in the adult cerebral cortex and cerebellum [82]. Buck et al. [15] and Dutrannoy et al. [83] identified five SCID patients with microcephaly, growth retardation, the occasional facial dysmorphic feature, and sensitivity to IR, due to NHEJ 1 mutations including the p.Arg178Ter truncation, the p.Asp166ArgfsTer20, the p.Arg176Ter or the compound mutation of a p.Arg57Gly and a p.Cys123Arg, called NHEJ1 syndrome.

\section{Ligase IV, DNA, ATP-dependent (LIG4) and X-ray repair, complementing defective, in chinese hamster (XRCC4)}

The LIG4-XRCC4 complex is responsible for the ligation of the two restored broken DNA ends during the final step in NHEJ. This complex is also an essential component of $\mathrm{V}(\mathrm{D}) \mathrm{J}$ recombination during the immune response [84]. LIG4 mutations result in LIG4 syndrome with immunodeficiency, developmental growth delay including unusual facial features, and pancytopenia that are quite similar to NBS $[41,42,85]$. One patient with 2 heterozygous single-nucleotide deletions (c.613DelT and c.1904delA) which resulted in a frameshift and a premature stop codon displayed lymphopenia, extreme radiosensitivity, primordial dwarfism, and neurological abnormalities including corpus callosum agenesis and colpocephaly [86].

On the other hand, a short stature, microcephaly, and endocrine dysfunction (SSMED) syndrome results from XRCC4 mutations such as the p.Trp43Arg substitution or premature termination codons $[47,87]$. Endocrine disorders seen in affected individuals included hypogonadism, goiter, diabetes mellitus and hypothyroidism $[88,89]$. Interestingly, one SSMED patient with microcephaly and progressive ataxia did not show any clinical immunodeficiency [89].

\section{Conclusion}

As summarized in Table 1, we have described here several rare human genetic diseases with genomic instability due to faulty DDR or damage repair defects. We have focused on genetic diseases with characteristic neurological phenotypes such as ataxia due to neurodegeneration in the cerebellum, neuropathy, microcephaly and mental retardation. As most of the proteins involved in DDR or damage repair are fundamental during development, lethality in utero is the expected outcome, when the machinery for DDR or damage repair is completely inactivated. Therefore, most of genetic diseases described herein are due to hypomorphic mutations.

It is becoming increasingly clear how abnormal DDR and damage repair result in neural manifestations. However, there is still much work to be done in order to gain the complete understanding of the molecular mechanisms and the development of new therapeutic strategies. One certainty is that DNA damage happens naturally during neurogenesis. 
Table 1. Summary of human genetic diseases resulting from defects in DNA damage repair

\begin{tabular}{|c|c|c|c|}
\hline & Syndrome & Responsible gene & Clinical phenotypes \\
\hline \multirow[t]{7}{*}{ DNA damage response defects } & Ataxia telangiectasia $(\mathrm{A}-\mathrm{T})$ & ATM (ataxia telangiectasia mutated) & $\begin{array}{l}\text { Progressive ataxia } \\
\text { Neuropathy } \\
\text { Immune system defects } \\
\text { Prone to tumors }\end{array}$ \\
\hline & Nijmegen breakage syndrome (NBS) & NBN (Nibrin) & $\begin{array}{l}\text { Microcephaly/mental retardation } \\
\text { Growth retardation } \\
\text { Unique craniofacial features } \\
\text { Immune system defects }\end{array}$ \\
\hline & $\begin{array}{l}\text { Ataxia telangiectasia like disorder } 1 \\
\text { (ATLD1) }\end{array}$ & MRE11 (meiotic recombination 11) & $\begin{array}{l}\text { Progressive ataxia } \\
\text { Neuropathy }\end{array}$ \\
\hline & $\begin{array}{l}\text { Ataxia telangiectasia like disorder } 2 \\
\text { (ATLD2) }\end{array}$ & PCNA (Proliferating cell nuclear antigen) & $\begin{array}{l}\text { Progressive ataxia } \\
\text { Learning difficulties } \\
\text { Growth retardation }\end{array}$ \\
\hline & Seckel syndrome 1 (SCKL1) & ATR (ataxia telangiectasia and Rad3 related) & $\begin{array}{l}\text { Microcephaly/mental retardation } \\
\text { Growth retardation } \\
\text { Unique craniofacial features }\end{array}$ \\
\hline & Seckel syndrome 2 (SCKL2) & RBBP8 (retinoblastoma binding protein 8) & $\begin{array}{l}\text { Microcephaly/mental retardation } \\
\text { Growth retardation } \\
\text { Unique craniofacial features }\end{array}$ \\
\hline & $\begin{array}{l}\text { Radiosensitivity, immunodeficiency, } \\
\text { dysmorphic features, learning } \\
\text { difficulties (RIDDLE) syndrome }\end{array}$ & RNF168 (ring finger protein 168) & $\begin{array}{l}\text { Progressive ataxia } \\
\text { Microcephaly/mental retardation } \\
\text { Learning difficulties } \\
\text { Growth retardation }\end{array}$ \\
\hline \multirow[t]{5}{*}{$\begin{array}{l}\text { DNA single strand break repair } \\
\text { defects }\end{array}$} & $\begin{array}{l}\text { Spinocerebellar ataxia, autosomal } \\
\text { recessive, with axonal neuropathy } \\
\text { (SCAN1) }\end{array}$ & TDP1 (tyrosyl-DNA phosphodiesterase 1) & $\begin{array}{l}\text { Progressive ataxia } \\
\text { Neuropathy } \\
\text { Seizure }\end{array}$ \\
\hline & Unnamed & TDP2 (tyrosyl-DNA phosphodiesterase 2) & $\begin{array}{l}\text { Progressive ataxia } \\
\text { Mental retardation } \\
\text { Seizure }\end{array}$ \\
\hline & Ataxia oculomotor apraxia 1 (AOA1) & APTX (aprataxin) & $\begin{array}{l}\text { Progressive ataxia } \\
\text { Neuropathy } \\
\text { Oculomotor apraxia }\end{array}$ \\
\hline & Ataxia oculomotor apraxia 2 (AOA2) & SETX (senataxin) & $\begin{array}{l}\text { Progressive ataxia } \\
\text { Neuropathy } \\
\text { Tremor } \\
\text { Oculomotor apraxia }\end{array}$ \\
\hline & $\begin{array}{l}\text { Microcephaly, seizures, and } \\
\text { developmental delay (MCSZ) }\end{array}$ & PNKP (polynucleotide kinase phosphatase) & $\begin{array}{l}\text { Microcephaly } \\
\text { Seizure } \\
\text { Growth retardation }\end{array}$ \\
\hline \multirow[t]{4}{*}{$\begin{array}{l}\text { DNA double strand break repair } \\
\text { defects }\end{array}$} & $\begin{array}{l}\text { Severe combined immunodeficiency } \\
\text { (SCID) }\end{array}$ & $\begin{array}{l}\text { PRKDC (protein kinase, DNA activated, } \\
\text { catalytic subunit) }\end{array}$ & $\begin{array}{l}\text { Microcephaly } \\
\text { Seizure } \\
\text { Growth retardation } \\
\text { Unique craniofacial features } \\
\text { Immune system defects }\end{array}$ \\
\hline & SCID, also NHEJ1 syndrome & NHEJ1 (non-homologous end joining factor 1) & $\begin{array}{l}\text { Microcephaly } \\
\text { Growth retardation } \\
\text { Unique craniofacial features } \\
\text { Immune system defects }\end{array}$ \\
\hline & LIG4 syndrome & LIG4 (DNA ligase IV) & $\begin{array}{l}\text { Growth retardation } \\
\text { Unique craniofacial features } \\
\text { Immune system defects }\end{array}$ \\
\hline & $\begin{array}{l}\text { Short stature, microcephaly, and } \\
\text { endocrine dysfunction (SSMED) }\end{array}$ & $\begin{array}{l}\text { XRCC4 (X-Ray repair, complementing } \\
\text { defective, in Chinese Hamster) }\end{array}$ & $\begin{array}{l}\text { Microcephaly } \\
\text { Endocrine dysfunction }\end{array}$ \\
\hline
\end{tabular}

However, the nature of this DNA damage is unknown. Several fundamental questions need to be answered: what is the origin of DNA damage in the developing brain, what type of DNA damage occurs during neurogenesis, and why some genetic diseases that arise due to genomic instability only affect the nervous system, even though every cell in the entire body carries 
the same mutations.

\section{Acknowledgements}

YSL is supported by the NRF of Korea grant funded by the MSIP (No. 2011-0030043 and NRF-2014R1A1A2056224). YSL is also supported by the new faculty research fund of Ajou University School of Medicine.

\section{References}

1. Kelner A. Effect of visible light on the recovery of streptomyces griseus conidia from ultra-violet irradiation injury. Proc Natl Acad Sci US A 1949;35:73-9.

2. Kelner A. Photoreactivation of ultraviolet-irradiated escherichia coli, with special reference to the dose-reduction principle and to ultraviolet-induced mutation. J Bacteriol 1949;58:511-22.

3. Friedberg EC. DNA repair and mutagenesis. 2nd ed. Washington, D.C.: ASM Press, 2006

4. Nigg EA. Genome instability in cancer development. New York: Springer, 2005.

5. Caldecott KW. Single-strand break repair and genetic disease. Nat Rev Genet 2008;9:619-31.

6. Madabhushi R, Pan L, Tsai LH. DNA damage and its links to neurodegeneration. Neuron 2014;83:266-82.

7. Goldstein M, Kastan MB. The DNA damage response: implications for tumor responses to radiation and chemotherapy. Annu Rev Med 2015;66:129-43.

8. Rass U, Ahel I, West SC. Defective DNA repair and neurodegenerative disease. Cell 2007;130:991-1004.

9. McKinnon PJ. Maintaining genome stability in the nervous system. Nat Neurosci 2013;16:1523-9.

10. McKinnon PJ. DNA repair deficiency and neurological disease. Nat Rev Neurosci 2009;10:100-12.

11. Abner CW, McKinnon PJ. The DNA double-strand break response in the nervous system. DNA Repair (Amst) 2004;3:1141-7.

12. Lamarche BJ, Orazio NI, Weitzman MD. The MRN complex in doublestrand break repair and telomere maintenance. FEBS Lett 2010;584: 3682-95.

13. You Z, Bailis JM. DNA damage and decisions: CtIP coordinates DNA repair and cell cycle checkpoints. Trends Cell Biol 2010;20:402-9.

14. Friedberg EC, Walker GC, Siede W. DNA repair and mutagenesis. Washington, DC: ASM Press, 1995.

15. Buck $D$, Malivert $L$, de Chasseval $R$, Barraud $A$, Fondanèche MC, Sanal 0 , et al. Cernunnos, a novel nonhomologous end-joining factor, is mutated in human immunodeficiency with microcephaly. Cell
2006;124:287-99.

16. Yano K, Morotomi-Yano K, Akiyama H. Cernunnos/XLF: a new player in DNA double-strand break repair. Int J Biochem Cell Biol 2009;41: 1237-40.

17. Rolig RL, McKinnon PJ. Linking DNA damage and neurodegeneration. Trends Neurosci 2000;23:417-24.

18. Al-Hakim A, Escribano-Diaz C, Landry MC, O'Donnell L, Panier S, Szilard RK, et al. The ubiquitous role of ubiquitin in the DNA damage response. DNA Repair (Amst) 2010;9:1229-40.

19. Stracker $T H$, Petrini JH. The MRE11 complex: starting from the ends. Nat Rev Mol Cell Biol 2011;12:90-103.

20. Williams GJ, Lees-Miller SP, Tainer JA. Mre11-Rad50-Nbs1 conformations and the control of sensing, signaling, and effector responses at DNA double-strand breaks. DNA Repair (Amst) 2010;9: 1299-306.

21. Panier S, Boulton SJ. Double-strand break repair: 53BP1 comes into focus. Nat Rev Mol Cell Biol 2014;15:7-18.

22. Lowndes NF. The interplay between BRCA1 and 53BP1 influences death, aging, senescence and cancer. DNA Repair (Amst) 2010;9:11126.

23. Chapman JR, Sossick AJ, Boulton SJ, Jackson SP. BRCA1-associated exclusion of 53BP1 from DNA damage sites underlies temporal control of DNA repair. J Cell Sci 2012;125:3529-34.

24. Daley JM, Sung P. 53BP1, BRCA1, and the choice between recombination and end joining at DNA double-strand breaks. Mol Cell Biol 2014;34:1380-8.

25. Nam EA, Cortez D. ATR signalling: more than meeting at the fork. Biochem J 2011;436:527-36.

26. Bakkenist CJ, Kastan MB. Chromatin perturbations during the DNA damage response in higher eukaryotes. DNA Repair (Amst) 2015;36:8-12.

27. Shiloh Y. ATM: expanding roles as a chief guardian of genome stability. Exp Cell Res 2014;329:154-61.

28. Shiloh Y, Ziv Y. The ATM protein kinase: regulating the cellular response to genotoxic stress, and more. Nat Rev Mol Cell Biol 2013;14:197-210.

29. Ambrose M, Gatti RA. Pathogenesis of ataxia-telangiectasia: the next generation of ATM functions. Blood 2013;121:4036-45.

30. Teive HA, Moro A, Moscovich M, Arruda WO, Munhoz RP, Raskin S, et al. Ataxia-telangiectasia-A historical review and a proposal for a new designation: ATM syndrome. J Neurol Sci 2015;355:3-6.

31. Huh HJ, Cho KH, Lee JE, Kwon MJ, Ki CS, Lee PH. Identification of ATM mutations in Korean siblings with ataxia-telangiectasia. Ann Lab Med 2013;33:217-20.

32. Falck J, Petrini JH, Williams BR, Lukas J, Bartek J. The DNA damagedependent intra-S phase checkpoint is regulated by parallel 
pathways. Nat Genet 2002;30:290-4.

33. Lim DS, Kim ST, Xu B, Maser RS, Lin J, Petrini JH, et al. ATM phosphorylates p95/nbs1 in an S-phase checkpoint pathway. Nature 2000;404:613-7.

34. Digweed M, Sperling K. Nijmegen breakage syndrome: clinical manifestation of defective response to DNA double-strand breaks. DNA Repair (Amst) 2004;3:1207-17.

35. Shimada H, Shimizu K, Mimaki S, Sakiyama T, Mori T, Shimasaki $\mathrm{N}$, et al. First case of aplastic anemia in a Japanese child with a homozygous missense mutation in the NBS1 gene (1171V) associated with genomic instability. Hum Genet 2004;115:372-6.

36. Taylor AM, Groom A, Byrd PJ. Ataxia-telangiectasia-like disorder (ATLD)-its clinical presentation and molecular basis. DNA Repair (Amst) 2004;3:1219-25

37. Baple EL, Chambers $H_{1}$ Cross $H E$, Fawcett $H$, Nakazawa $Y$, Chioza BA, et al. Hypomorphic PCNA mutation underlies a human DNA repair disorder. J Clin Invest 2014;124:3137-46.

38. Mailand N, Gibbs-Seymour I, Bekker-Jensen S. Regulation of PCNAprotein interactions for genome stability. Nat Rev Mol Cell Biol 2013;14:269-82.

39. Moldovan GL, Pfander B, Jentsch S. PCNA, the maestro of the replication fork. Cell 2007;129:665-79.

40. O'Driscoll M, Gennery AR, Seidel J, Concannon P, Jeggo PA. An overview of three new disorders associated with genetic instability: LIG4 syndrome, RS-SCID and ATR-Seckel syndrome. DNA Repair (Amst) 2004;3:1227-35.

41. Ben-Omran TI, Cerosaletti $K$, Concannon P, Weitzman S, Nezarati MM. A patient with mutations in DNA Ligase IV: clinical features and overlap with Nijmegen breakage syndrome. Am J Med Genet Part A 2005;137A:283-7.

42. Chistiakov DA, Voronova NV, Chistiakov AP. Ligase IV syndrome. Eur J Med Genet 2009;52:373-8.

43. Ogi T, Walker S, Stiff T, Hobson E, Limsirichaikul S, Carpenter G, et al. Identification of the first ATRIP-deficient patient and novel mutations in ATR define a clinical spectrum for ATR-ATRIP Seckel Syndrome. PLoS Genet 2012;8:e1002945.

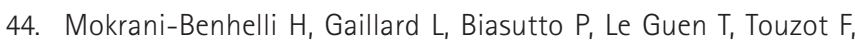
Vasquez $N_{1}$ et al. Primary microcephaly, impaired DNA replication, and genomic instability caused by compound heterozygous ATR mutations. Hum Mutat 2013;34:374-84.

45. Tanaka A, Weinel S, Nagy N, O'Driscoll M, Lai-Cheong JE, Kulp-

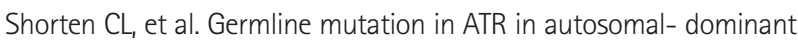
oropharyngeal cancer syndrome. Am J Hum Genet 2012;90:511-7.

46. Børglum AD, Balslev $T$, Haagerup $A$, Birkebaek $N$, Binderup $H_{\text {, }}$ Kruse TA, et al. A new locus for Seckel syndrome on chromosome 18p11.31-q11.2. Eur J Hum Genet 2001;9:753-7.
47. Shaheen R, Fageih E, Ansari S, Abdel-Salam G, Al-Hassnan ZN, AlShidi $T_{1}$ et al. Genomic analysis of primordial dwarfism reveals novel disease genes. Genome Res 2014;24:291-9.

48. Qvist $P$, Huertas $P_{1}$ Jimeno $S$, Nyegaard $M$, Hassan MJ, Jackson SP, et al. CtIP mutations cause Seckel and Jawad syndromes. PLoS Genet 2011;7:e1002310.

49. Makharashvili N, Paull TT. CtIP: a DNA damage response protein at the intersection of DNA metabolism. DNA Repair (Amst) 2015;32:7581.

50. Hassan MJ, Chishti MS, Jamal SM, Tariq M, Ahmad W. A syndromic form of autosomal recessive congenital microcephaly (Jawad syndrome) maps to chromosome 18p11.22-q11.2. Hum Genet 2008;123:77-82.

51. Al-Dosari MS, Shaheen R, Colak D, Alkuraya FS. Novel CENPJ mutation causes Seckel syndrome. J Med Genet 2010;47:411-4.

52. Dauber A, Lafranchi SH, Maliga Z, Lui JC, Moon JE, McDeed C, et al. Novel microcephalic primordial dwarfism disorder associated with variants in the centrosomal protein ninein. J Clin Endocrinol Metab 2012;97:E2140-51.

53. Kalay E, Yigit $G$, Aslan Y, Brown KE, Pohl E, Bicknell LS, et al. CEP152 is a genome maintenance protein disrupted in Seckel syndrome. Nat Genet 2011;43:23-6.

54. Sir JH, Barr AR, Nicholas AK, Carvalho OP, Khurshid M, Sossick $A$, et al. A primary microcephaly protein complex forms a ring around parental centrioles. Nat Genet 2011;43:1147-53.

55. Shanske A, Caride DG, Menasse-Palmer L, Bogdanow A, Marion RW. Central nervous system anomalies in Seckel syndrome: report of a new family and review of the literature. Am J Med Genet 1997;70: 155-8.

56. Ronchi D, Di Fonzo A, Lin W, Bordoni A, Liu C, Fassone E, et al. Mutations in DNA2 link progressive myopathy to mitochondrial DNA instability. Am J Hum Genet 2013;92:293-300.

57. Devgan SS, Sanal O, Doil C, Nakamura K, Nahas SA, Pettijohn $K$, et al. Homozygous deficiency of ubiquitin-ligase ring-finger protein RNF168 mimics the radiosensitivity syndrome of ataxiatelangiectasia. Cell Death Differ 2011;18:1500-6.

58. Stewart GS, Panier S, Townsend K, Al-Hakim AK, Kolas NK, Miller ES, et al. The RIDDLE syndrome protein mediates a ubiquitin-dependent signaling cascade at sites of DNA damage. Cell 2009;136:420-34.

59. Pommier Y, Huang SY, Gao R, Das BB, Murai J, Marchand C. TyrosylDNA-phosphodiesterases (TDP1 and TDP2). DNA Repair (Amst) 2014;19:114-29.

60. Takashima H, Boerkoel CF, John J, Saifi GM, Salih MA, Armstrong $D$, et al. Mutation of TDP1, encoding a topoisomerase I-dependent DNA damage repair enzyme, in spinocerebellar ataxia with axonal neuropathy. Nat Genet 2002;32:267-72. 
61. El-Khamisy SF, Saifi GM, Weinfeld M, Johansson $F_{1}$ Helleday $T$, Lupski $J R$, et al. Defective DNA single-strand break repair in spinocerebellar ataxia with axonal neuropathy-1. Nature 2005;434:108-13.

62. Pype S, Declercq W, Ibrahimi A, Michiels C, Van Rietschoten JG, Dewulf $N$, et al. TRRAP, a novel protein that associates with CD40, tumor necrosis factor (TNF) receptor-75 and TNF receptor-associated factors (TRAFs), and that inhibits nuclear factor-kappa B activation. J Biol Chem 2000;275:18586-93.

63. Cortes Ledesma F, El Khamisy SF, Zuma MC, Osborn K, Caldecott KW. A human 5'-tyrosyl DNA phosphodiesterase that repairs topoisomerase-mediated DNA damage. Nature 2009;461:674-8.

64. Gómez-Herreros F, Schuurs-Hoeijmakers JH, McCormack M, Greally MT, Rulten S, Romero-Granados R, et al. TDP2 protects transcription from abortive topoisomerase activity and is required for normal neural function. Nat Genet 2014;46:516-21.

65. McKinnon PJ. TDP2 keeps the brain healthy. Nat Genet 2014;46:41921.

66. Clements PM, Breslin C, Deeks ED, Byrd PJ, Ju L, Bieganowski P, et al. The ataxia-oculomotor apraxia 1 gene product has a role distinct from ATM and interacts with the DNA strand break repair proteins XRCC1 and XRCC4. DNA Repair (Amst) 2004;3:1493-502.

67. Gueven N, Becherel OJ, Kijas AW, Chen P, Howe O, Rudolph JH, et al. Aprataxin, a novel protein that protects against genotoxic stress. Hum Mol Genet 2004;13:1081-93.

68. Ahel I, Rass U, El-Khamisy SF, Katyal S, Clements PM, McKinnon PJ, et al. The neurodegenerative disease protein aprataxin resolves abortive DNA ligation intermediates. Nature 2006;443:713-6.

69. Date H, Onodera O, Tanaka H, Iwabuchi K, Uekawa K, Igarashi S, et al. Early-onset ataxia with ocular motor apraxia and hypoalbuminemia is caused by mutations in a new HIT superfamily gene. Nat Genet 2001;29:184-8.

70. Moreira MC, Barbot C, Tachi N, Kozuka N, Uchida E, Gibson T, et al. The gene mutated in ataxia-ocular apraxia 1 encodes the new HIT/ Zn-finger protein aprataxin. Nat Genet 2001;29:189-93.

71. Aicardi J, Barbosa C, Andermann E, Andermann F, Morcos R, Ghanem $\mathrm{Q}$, et al. Ataxia-ocular motor apraxia: a syndrome mimicking ataxiatelangiectasia. Ann Neurol 1988;24:497-502.

72. van Minkelen $R$, Guitart M, Escofet $C$, Yoon G, Elfferich $P$, Bolman $\mathrm{GM}$, et al. Complete APTX deletion in a patient with ataxia with oculomotor apraxia type 1. BMC Med Genet 2015;16:61.

73. Yoon G, Westmacott R, Macmillan L, Quercia N, Koutsou P, Georghiou $A$, et al. Complete deletion of the aprataxin gene: ataxia with oculomotor apraxia type 1 with severe phenotype and cognitive deficit. BMJ Case Rep 2009. doi: 10.1136/bcr.08.2008.0688.

74. Moreira MC, Klur S, Watanabe M, Németh AH, Le Ber I, Moniz JC, et al. Senataxin, the ortholog of a yeast RNA helicase, is mutant in ataxia-ocular apraxia 2. Nat Genet 2004;36:225-7.

75. Suraweera A, Becherel $0 J$, Chen P, Rundle N, Woods R, Nakamura $J$, et al. Senataxin, defective in ataxia oculomotor apraxia type 2 , is involved in the defense against oxidative DNA damage. J Cell Biol 2007:177:969-79.

76. Al Tassan N, Khalil D, Shinwari J, Al Sharif L, Bavi P, Abduljaleel Z, et al. A missense mutation in PIK3R5 gene in a family with ataxia and oculomotor apraxia. Hum Mutat 2012;33:351-4.

77. Jilani A, Ramotar D, Slack C, Ong C, Yang XM, Scherer SW, et al. Molecular cloning of the human gene, PNKP, encoding a polynucleotide kinase 3'-phosphatase and evidence for its role in repair of DNA strand breaks caused by oxidative damage. J Biol Chem 1999;274:24176-86.

78. Shen J, Gilmore EC, Marshall CA, Haddadin M, Reynolds JJ, Eyaid W, et al. Mutations in PNKP cause microcephaly, seizures and defects in DNA repair. Nat Genet 2010;42:245-9.

79. Bras J, Alonso I, Barbot C, Costa MM, Darwent L, Orme T, et al. Mutations in PNKP cause recessive ataxia with oculomotor apraxia type 4. Am J Hum Genet 2015;96:474-9.

80. Jette N, Lees-Miller SP. The DNA-dependent protein kinase: a multifunctional protein kinase with roles in DNA double strand break repair and mitosis. Prog Biophys Mol Biol 2015;117:194-205.

81. Woodbine L, Neal JA, Sasi NK, Shimada M, Deem K, Coleman H, et al. PRKDC mutations in a SCID patient with profound neurological abnormalities. J Clin Invest 2013;123:2969-80.

82. Cantagrel V, Lossi AM, Lisgo S, Missirian C, Borges A, Philip N, et al. Truncation of NHEJ1 in a patient with polymicrogyria. Hum Mutat 2007;28:356-64.

83. Dutrannoy V, Demuth I, Baumann U, Schindler D, Konrat K, Neitzel $\mathrm{H}$, et al. Clinical variability and novel mutations in the NHEJ1 gene in patients with a Nijmegen breakage syndrome-like phenotype. Hum Mutat 2010;31:1059-68.

84. Tomkinson AE, Mackey ZB. Structure and function of mammalian DNA ligases. Mutat Res 1998;407:1-9.

85. O'Driscoll M, Cerosaletti KM, Girard PM, Dai Y, Stumm M, Kysela $B$, et al. DNA ligase IV mutations identified in patients exhibiting developmental delay and immunodeficiency. Mol Cell 2001;8:117585.

86. IJspeert H, Warris A, van der Flier M, Reisli I, Keles S, Chishimba S, et al. Clinical spectrum of LIG4 deficiency is broadened with severe dysmaturity, primordial dwarfism, and neurological abnormalities. Hum Mutat 2013;34:1611-4.

87. Murray JE, van der Burg M, IJspeert H, Carroll P, Wu Q, Ochi T, et al. Mutations in the NHEJ component XRCC4 cause primordial dwarfism. Am J Hum Genet 2015;96:412-24.

88. de Bruin C, Mericq V, Andrew SF, van Duyvenvoorde HA, Verkaik NS, 
Losekoot M, et al. An XRCC4 splice mutation associated with severe short stature, gonadal failure, and early-onset metabolic syndrome. J Clin Endocrinol Metab 2015;100:E789-98.

89. Guo C, Nakazawa Y, Woodbine L, Björkman A, Shimada M, Fawcett

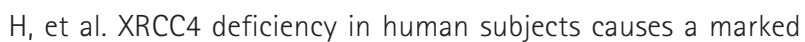
neurological phenotype but no overt immunodeficiency. J Allergy Clin Immunol 2015;136:1007-17. 